$1-1-1890$

\title{
Additional reports upon wheat distributed in 1889; Meteorological report for July; Reports of correspondents upon meteorology and crops for July
}

John A. Myers

Follow this and additional works at: https://researchrepository.wvu.edu/ wv_agricultural_and_forestry_experiment_station_bulletins

\section{Digital Commons Citation}

Myers, John A., "Additional reports upon wheat distributed in 1889 ; Meteorological report for July ; Reports of correspondents upon meteorology and crops for July" (1890). West Virginia Agricultural and Forestry Experiment Station Bulletins. 9.

https://researchrepository.wvu.edu/wv_agricultural_and_forestry_experiment_station_bulletins/9 @ WVU. It has been accepted for inclusion in West Virginia Agricultural and Forestry Experiment Station Bulletins by an authorized administrator of The Research Repository @WVU. For more information, please contact ian.harmon@mail.wvu.edu. 
West Virginia University Libraries

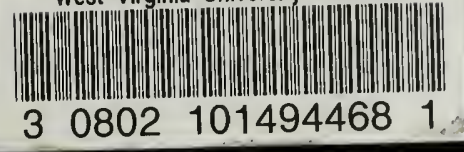





\section{BULLFTIN NO. 9.}

OF THE

\section{WEST VIRGINIA}

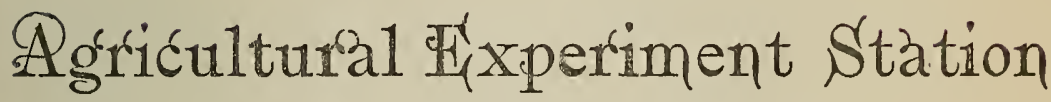 JULY, 1890.}

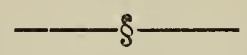

I. Additional Reports upon Wheat Distributed in 1889.

II. Meteorological Report for July.

III. Reports of Correspondents upon Meteorology and Crops for July.

By JoHn A. Myers, Director.

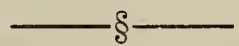

The director does not hold himself responsible for the opinions of Correspondents.
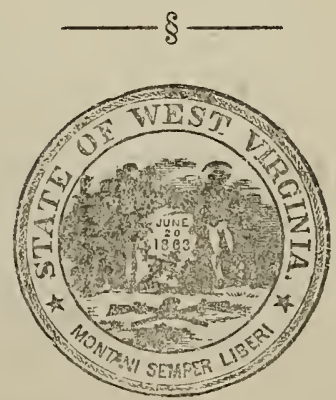

CHARLESTON :

Moseb W. Donnality, Public Printer, 1890. 
BOARD OF REGENTS OF TFE WEST VIRGINIA UNIVERSITY.

District.

1. J. B SOMMERVILLE,

2. CLARENCE L. SMITH,

3. PEREGRIN HAYES,

4. D. D. JOHNSON,

5. JOHN G. SCHILLING,

6. EDWARD A. BENNETT,

7. WIRT A. FRENCH,

8. M. J. KESTER,

9. D. C. GALLAHER,

10. THOMAS J. FARNSWORTH,

11. JOSEPH MORELAND,

12. JOHN A. ROBINSON,

13. DR. W. W. BROWN,
P. O. Address.

Wheeling.

Fairmont.

Glenville.

Long Reach.

Spencer.

Huntington.

Princeton.

Union.

Charleston.

Buckhannon.

Morgantown.

Patterson Depot.

Kabletown.

\section{MEMBERS OF THE STATION COMMITTEE.}

JOHN A. ROBINSON, JOSEPE MORELAND,
JOHN G. SHILLING, THOMAS J. FARNSWORTH,

DR. W. W. BROWN.

President of the University.

E. M. TURNER, LL. D.,
Treasurer.

JOHN I. HARVEY,

\section{STATION STAFF.}

JOHN A. MYERS, PH. D.,

O. F. MILLSPAUGH, M, D.,

D. D. JOHNSON, A. M., H. R. BALDWIN, JR.,

A. D. HOPKINS, SUSIE V. MAYERS,
Director Botanist and Microscopist. - Agriculturist.

Chemist.

Special Agent Entomology. - Stenographer and _Book-keeper. 


\section{ADDITIONAL REPORTS UPON WHEAT DISTRIBUTED IN 'THE FALL OF 1887.}

Variety of wheat tested "Velvet Chaff."

Seed was not pure, it contained cockle.

Sowed $1 \frac{1}{2}$ bushels per acre September $8,18 \varepsilon 9$, on sandy loam clay soil, prepared by plowing, harrowing and rubbing until it. was in fine condition, then drilled. Condition of soil at time of sowing was good. Land was in pasture in 1887. Soil is considered good for wheat. The weather following sowing was favorable for the growth of wheat, and stand secured in the fall was good. Think it would withstand frost and drought. Ripened about July 1. Yield 12 bushels per acre. Owing to the cold and wet spring, the crop was cut short one-fourth in my opinion. Think it might be a good wheat under more favorable conditions; but was not so good as some other varieties in this vicinity under same conditions.

\section{E. J. OWINGS,}

Holliday's Cove, W. Va.

Variety of wheat tested "Golden Amber."

Seed was mixed and had cockle in it.

Sowed $1 \frac{1}{2}$ bushels per acre on September 8, 1889, on sandy loam soil prepared by plowing, harrowing, drilling. Soil was in grod condition at time of sowing. Land in 1887 was in pasture. Soil is considered good for wheat. Weather following was unfavorable for growth of wheat. Stand of wheat secured in the fall was good. Cold and wet weather retarded growth of wheat in the spring. Ripened 1st of July. Yield 15 bushels per acre. I think it a fair wheat, has a nice clear hard grain; but a short head well filled. Is a bearded wheat, which is against it. Think it better wheat than "Velvet Chaff." Did not yield a full crop owing to wet spring.

E. J. OWINGS, Holliday's Cove, W. Va.

Variety of wheat tested, "Michigan Bronze."

Qaulity of seed was good; but contained some cockle.

Sowed $1 \frac{1}{2}$ bushels per acre September 8, 1889, on sandy loam clay soil, prepared by plowing, harrowing, rubbing or dragging with a plank drag, and drilled. Cor dition of soil at tiue of sow. ing was good. Land was in pasture in 1887. This soil is considered good for wheat. Weather following sowing was good for growth of wheat, and stand secured in the fall was good. Ripened July 5. Yield $1 \mathrm{~s}$ bushels to the acre. It was the only wheat in the field that any one has arked for seed. Much like the "Pool," but bearded. I consider it the most valuable to the farmers of West Virginia of the three variefies tested.

E. J. OWINGS, Holliday's Cove, W. Va. 


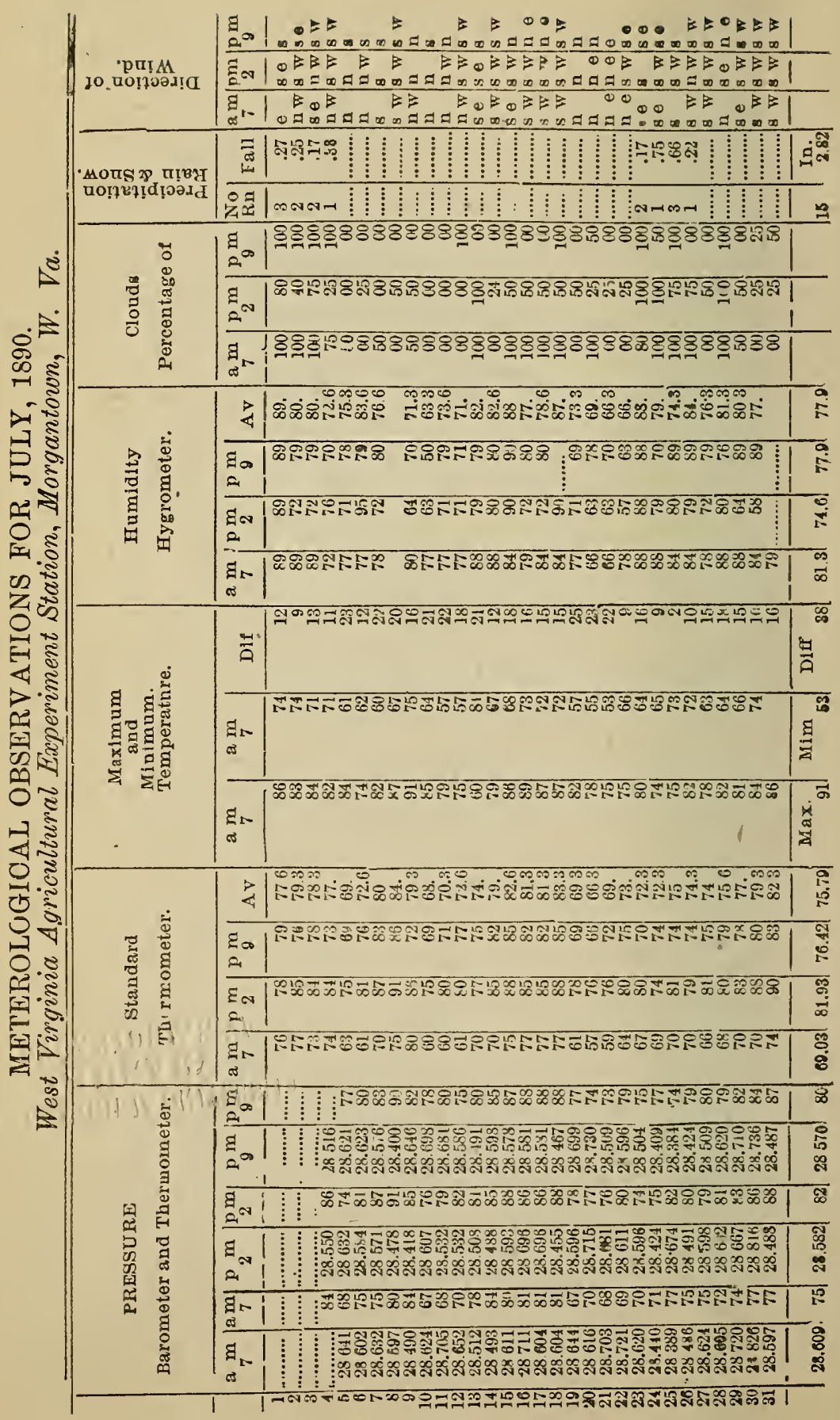




\section{REPORTS OF CORRESPONDENTS.}

REPORT OF W. C. KISEN-FRANKLIN, PENDLETON CO.

For the Month of July, 1890.

Weather very hot and dry. Very little rain. Warmer weather than has been for years. Corn short. Wheat half crop, or about 9 bushels per acre. Oats light. Buckwheat not more than half crop. Grass heavy and hay well made, as the weather has been fine for haying. The Texas fly has made its appoarance among the cattle and is very annoying. Cattle not doing well. Horses doing well, prices low. Sheep doing well, prices good. Swine well, but scarce. Poultry well. No new improvements.

W. C. KISEN.

REPORT OF ADAM FISHER-MOOREFIELD, HARDY CO.

For the Month of July, 1890.

Weather exceedingly hot and dry up to the 24 th. On the 25 th it rained, say half inch. Corn is injured by the drought, especially on the uplands. On the bottoms a prospect for two-thirds of a crop. Oats generally in the shock and light, meadows heavy and secured in good condition. Pastures parched. All kinds of stock in good condition. No disease among them. Market price low. New enterprise hoped for, but nothing in sight. Products, corn, wheat and grass. This month has been exceedingly hot, much of the time above 90.

Adam Fisher.

REPORT OF W. A. MORGAN- SHEPHERDSTOWN, JRFFERSON CO.

For the Month of July, 1890.

Weather unusually dry with severe storms of thunder and lightning. Mure electricity than usual. Corn growing well. Wheat succeeds in making from 20 to 28 bushels per acre by those who hare threshed. Oats a good crop. Grass an excellent yield. 'No buckwheat, and but very little barley raised in this county. Fruit almost a total failure. Condition of stock good and thrifty, no disease reported. Market generally good, with a good demand for beef cattle and sheep since last June. Products, wheat, corn, oats, potatoes, stock raising. Fruit raising more is profitable as the market for grain has been poor for several years. The general condition of farms good, with crops harvested and in good condition.

W. A. Morgan. 
REPORT OF WM. HAYNES-STOCK YARDS, W. VA., SUYMERS 00.

\section{For Month of July, 1890.}

Weather, severe; burning drought. Corn wilting for want of rain; very short. Wheat harvested in good order; crop short. Grass burned up for want of rain. Fruits none. Oats worthless. Condition of live stock, fair. Grass scarce; will check increase in weight. No disease attacking stock. The market seems to be advancing, and demand increasing. Nothing new, but tan bark, grain, grass, and stock growing.

War. HAYNES.

REPORT OP J. P. HALE-CHARLESTON, W. VA., KANAWHA CO.

For Month of July, 1890.

Weatber quite warm. Very little rain. Corn crop looks well, will be an average crop or over. Wheat not over half a crop. Oats a failure. Barley not raised. Buckwheat, none. Grass, good. Fruit almost a failure, killed by early frosts. Condition of live stock, fairly good. Nothing special to note relating to any of them. Market cattle real low. Horses and mules well up. Healthy condition generally. Nothing new of special importance. Industry same as before.

J. P. Hale.

REPORT OF J. W. CARTER-PLEASANT DALE, HAXPSHIRI 00.

For Month of July, 1890.

Weather mostly dry and very hot. Corn short and needing rain. Wheat is harvested and proves rather a surprise to our farmers. When they began to harvest they found the crop about three-fourths instead of one-fourth. Oats not filled, about one half crop. Hay crop good and mostly harvested in good condition. Condition good; no disease reported. Market for cattle very flat. Large horses in demand. Sheep active and high. Swine active. Poultry market good. Hope to report some new enterprise soon.

J. W. Cartrur.

REPORT OF GEO. T. HGBERT-RAVEN'S EYE, FAYETTI

For the Month of July, 1890.

Weather, frequent showers, in consequence of which harvest has been delayed. Hay crop good. Pasture getting short. Corn looking well. Oats almost a failure. Fruit crop in this section a complete failure. Live stock in good condition, but with the ex- 
oeption of sheep, there is no demand; the latter are scarce and high.

George T. EgBert.

REPORT OF W. G. AND M. O. RILEY--ELK CITY, BARBOUR OO.

$$
\text { For Month of July, } 1890 .
$$

Weather warm and dry; two or three very light showers. Corn lonks well, but it must have rain soon or it won't amount to much. Wheat is thrashing out about half crop. Oats about half crop. Too dry for buckwheat. Hay very good. Pasture drying up. Condition of stock good. Market for horses and cattle dull. sheep are good; no disease among them. Stock raising is our principal industry. We don't grow enough grain for home use. The farmers liked the instructions delivered by Mr. Johnson, at Phillipi, during the institute.

W. G. \& M. C. RILEY.

RIPORT OF S. R. HANEN-GLEN EASTON, MARSHALL CO.

For Month of July, 1890

Weather warm and dry. Fall of rain very limited. Wheat not filled, about 50 per cent. Corn suffering from drought, perhaps 75 per cent. Oats 75 per cent. Grass good, 100 per cent. H'ruit almost an entire failuro, not more than 20 per cent. Potatoes not good, about 45 per cent. Stock in good condition, some pinkeye reported in the northern end of the county. Some cholera among the poultry. Market good. The B. \& O. Railroad is grading for large shops and round houses at Benwood.

S. R. HANen.

RHPORT OF SAMUEL A. HOUSTON-PICKAWAY, MONROE CO.

For the Month of July, 1890.

Weather very dry. One half crop of corn. Wheat 60 per cent. Arass 90 per cent. Fruit very little. All stock have done well -no disease. Market low. One creamery. Stock raising. SAMUEL A. Houston.

RRPORT OF R. A. ALEXANDER-CHARLESTOWN, JEFFERSON 00.

For the Month of July, 1890.

Moderate rains. We will have a very fair crop of corn. The wheat turning out from the machines fairly well ; quality good. Live stock in fine condition, with moderate prices. We are trying to extend our town by selling stock in a land company, and hope to 
bring enterprises. Wheat, corn and cattle. Our farmers are going largely into sheep this year, finding them very profitable. R. A. AluXANDER.

REPORT OF A. W. WESTFALL-AUBURN, RITCHIE CO.

For Month of July, 1890.

Weather, very little rain, no snow. Same condition as last report, except fruit crop, which is almost an entire failure. Condition of stock good; ordinary market. New enterprises, none. Grain and stock raising. Every thing in very good condition.

A. W. Westfall. 


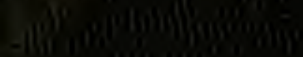

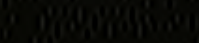

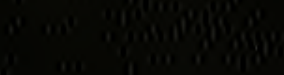

